\title{
Upaya Guru Pendidikan Agama Islam dalam Pembentukan Kepribadian Islam Siswa di SMA Negeri 2 Kelayang Kabupaten Indragiri Hulu
}

\author{
HAMZAH* \\ SYAHRAINI TAMBAK** \\ NELLA ARIYANI***
}

*Fakultas Agama Islam (FAI) Universitas Islam Riau (UIR) Pekanbaru

Jl. Kaharuddin Nasution, No. 113, Perhentian Marpoyan Pekanbaru 28284

**Fakultas Agama Islam (FAI) Universitas Islam Riau (UIR) Pekanbaru

Jl. Kaharuddin Nasution, No. 113, Perhentian Marpoyan Pekanbaru 28284

e-mail: syahraini tambak@yahoo.co.id

***Fakultas Agama Islam (FAI) Universitas Islam Riau (UIR) Pekanbaru
Jl. Kaharuddin Nasution, No. 113, Perhentian Marpoyan Pekanbaru 28284

\begin{abstract}
Abstrak: Dalam Islam kepribadian merupakan salah satu faktor yang sangat penting, bahwa tujuan pendidikan Islam tertuju pada pembentukan kepribadian. Di zaman sekarang ini, banyak siswa yang belajar Pendidikan Agama Islam tetapi dalam dirinya belum terbentuk kepribadian Islam. Begitu juga dalam penelitian yang penulis lakukan di SMA Negeri 2 Kelayang kabupaten Indragiri Hulu penulis menemukan gejala-gejala yang terjadi diantaranya: guru kurang membiasakan siswa untuk mengucapkan salam ketika bertemu guru dan siswa lainnya, kurangnya kesopanan siswa ketika bertegur sapa dengan guru, kurangnya bimbingan dalam melaksanakan ibadah serta banyak siswa yang bertutur kata kurang sopan dan mengucapkan katakata kotor. Rumusan masalah dalam penelitian ini adalah apa saja upaya guru Pendidikan Agama Islam dalam pembentukan kepribadian Islam siswa di SMA Negeri 2 Kelayang. Tujuan penelitian untuk mengetahui upaya guru Pendidikan Agama Islam dalam pembentukan kepribadian Islam siswa di SMA Negeri 2 Kelayang kabupaten Indragiri Hulu. Adapun jenis penelitian yang digunakan dalam penelitian ini adalah penelitian studi kasus. Tempat penelitian di SMA Negeri 2 Kelayang kabupaten Indragiri Hulu. Subjek penelitian adalah guru PAI di SMA Negeri 2 Kelayang, objek penelitian adalah upaya guru PAI dalam pembentukan kepribadian Islam siswa di SMA Negeri 2 Kelayang. Populasi penelitian 1 orang guru PAI di SMA Negeri 2 Kelayang kabupaten Indragiri Hulu. Teknik pengumpul data adalah wawancara dan dokumentasi. Berdasarkan pengolahan dan analisis data dapat disimpulkan upaya guru Pendidikan Agama Islam dalam pembentukan kepribadian Islam siswa di SMA Negeri 2 Kelayang kabupaten Indragiri Hulu dengan memberikan penjelasan kepada siswa mengenai maksud dari kepribadian mukmin, muslim dan muhsin, guru juga memberikan contoh dan menyuruh siswa untuk mengaplikasikannya dalam kehidupan sehari-hari baik di lingkungan sekolah maupun di lingkungan masyarakat, guru juga mengajarkan kepada siswa untuk meneladani sifat-sifat yang baik sesuai dengan penjelasan materi dari kepribadian mukmin, muslim dan muhsin serta menanamkannya di kehidupan sehari-hari.
\end{abstract}

Kata kunci: Upaya, Guru PAI, Pembentukan Kepribadian.

Jurnal Al-hikmah Vol. 14, No. 1, April 2017 ISSN 1412-5382 


\section{PENDAHULUAN}

Pendidikan adalah usaha sadar dan terencana untuk mewujudkan suasana belajar dan proses pembelajaran agar peserta didik secara aktif mengembangkan potensi dirinya untuk melakukan spritual keagamaan, pengendalian diri, kepribadian, kecerdasan, akhlak mulia, serta keterampilan yang diperlukan dirinya, masyarakat, bangsa, dan negara (Undang-Undang No. 20 Tahun 2003).

Pendidikan merupakan suatu pondasi yang dapat mencegah seseorang melakukan perbuatan tidak terpuji, terlebih lagi pendidikan agama. M. Arifin membagi tugas pendidikan agama Islam, antara lain mempertahankan, menanamkan nilainilai Islam yang bersumber dari kitabkitab suci Al-Qur'an dan Al-Hadis. Nilai Islami yang harus dikembangkan dalam pribadi anak didik melalui proses kependidikan adalah berwatak fleksibel dan dinamis dalam konfigurasi normatif yang tak berubah sepanjang masa (Helly Rahmayandi dalam M. Arifin, 2013: 2-3).

Menurut Hasbullah (1996:1) mengatakan bahwa pendidikan sebagai usaha manusia untuk membina kepribadiannya sesuai dengan nilainilai di dalam masyarakat dan kebudayaan. Dalam perkembangannya, istilah pendidikan atau paedagogie berarti bimbingan atau pertolongan yang diberikan dengan sengaja oleh orang dewasa agar ia menjadi dewasa.

Dapat dipahami bahwa watak (kepribadian) bersifat lebih luas dan mencakup di dalamnya konstitusi dan tempramen. Oleh karna itu watak (kepribadian) ada yang dapat dipengaruhi oleh faktor eksogen (luar) dan ada pula yang tidak. Konstitusi dan tempramen cendrung bersifat tetap dan sulit untuk diubah, kalu pun terjadi perubahan, namun perubahan tersebut tidak menetap (Salmaini Yeli, 2012: 7778).

Kepribadian sangat perlu di ketahui dan di pelajari karna kepribadian sangat berkaitan erat dengan pola penerimaan lingkungan sosial terhadap seseorang. Orang yang memiliki kepribadian sesuai dengan pola yang dianut oleh masyarakat di lingkungannya, akan mengalami penerimaan yang baik, tetapi sebaliknya jika kepribadian seserang tidak sesuai, apalagi bertentangan dengan pola yang dianut lingkungannya, maka akan terjadi penolakan dari masyarakat (Djaali, 2008: 1).

Dalam Islam kepribadian merupakan salah satu faktor yang sangat penting, bahwa tujuan pendidikan Islam tertuju pada pembentukan kepribadian. Zakiah Drajat (1992) menggambarkan tujuan pendidian Islam adalah terwujudnya kepribadian seseorang yang membuatnya menjadi "insan kamil" dengan pola taqwa. Insan kamil artinya manusia utuh rohani dan jasmani dapat hidup secara wajar dan normal karna taqwanya kepada Allah SWT ( Salmaini Yeli, 2012: 86-87).

Kepribadian tumbuh dan berkembang sepanjang hidup manusia, terutama sejak lahir sampai masa remaja yang selalu berada di lingkungan keluarga, diasuh oleh orang tua, dan bergaul dengan anggota keluarga lainnya. Pengaruh dan peranan keluarga serta orang tua dalam membentuk/menempa pribadi seorang anak cukup besar ( Abu Ahmadi, 2005:167).

Menurut Muhammad Nur Abd Haid pembinaan kepibadian harus di lakukan sejak anak berusia dini. Dari usia dini hingga baligh itu ada sembilan macam pembinaan, yaitu:

Pembinaan Aqidah; (b) Pembinaan Ibadah; (c) Pembinaan Mental 
Bermasyarakat; (d) Pembinaan Akhlak; (e) Pembinaan Perasaan dan Kejiwaan; (f) Pembinaan Jasmani; (g) Pembinaan Intelektual; (h) Pembinaan Kesehatan; dan (i) Pembinaan Etika seksual (Jurnal Pendidikan Islam Nur Jamal Volume 8, Nomor 2, 2015:84-85).

Menurut Bruce Perry seorang peneliti dari Baylor College of Medicine AS mengemukakan bahwa perilaku buruk juga di sebabkan oleh perubahan struktur dan kerja pada otak. Adapun Sumarmo Markam berkesimpulan bahwa kepribadian tersebut dapat di lihat dari perilaku seseorang yang di bentuk melalui amigdala, yaitu bagian dalam sistem limbik pada otak manusia yang berfungsi sebagai pusat perasaan (Djaali, 2008: 2-3).

Dalam kaitannya dengan pendidikan agama dalam kehidupan manusia, maka dalam membina dan membentuk pribadi anak didik perlu kiranya dengan mengadakan pendekatan dan perhatian yang bersifat tuntunan dan bimbingan. Karena pendidikan agama menjamin untuk memperbaiki akhlak anak-anak dan mengangkat mereka kederajat yang tinggi, serta berbahagia dalam hidup dan kehidupannya. Pendidikan agama juga merupakan usaha yang dilakukan secara sistematis dalam membimbing siswa yang beragama Islam, sehingga ajaran Islam benar-benar diketahui, dimiliki, dan di amalkan oleh peserta didik baik tercermin dalam sikap, maupun cara berfikirnya. Melalui pendidikan agama terjadilah proses pengembangan aspek kepribadian anak, yaitu aspek kognitif, aspek afektif, dan aspek psikomotorik. Sehingga ajaran agama diharapkan akan menjadi bagian integral dari pribadi anak yang bersangkutan. Dalam arti segala aktifitas anak akan mencerminkan sikap Islamiyah (Ahmad Busyro dalam Mahmud Yunus, 2011: 4-5).
Dizaman sekarang ini, banyak siswa yang belajar pendidikan Islam tetapi dalam dirinya belum terbentuk kepribadian Islam tersebut. Bisa dilihat dari cara berpakaian, pergaulan, tingkah laku dan hal-hal lainnya. Pada kenyataannya juga, banyak siswa yang belajar pendidikan agama Islam, namun masih banyak juga akhlak dalam pergaulannya kurang mencerminkan seorang siswa yang beragama Islam.

Pada dasarnya peranan seorang guru Pendidikan Agama Islam dalam membentuk kepribadian seorang anak sangat besar. Guru sebagai pendidik utama dan juga suri tauladan bagi siswanya. Seorang guru agama dituntut untuk dapat berupaya membawa siswanya kearah kehidupan keagamaan yang sesuai dengan ajaran Islam. Serta berupaya membentuk siswa yang memiliki kepribadian sesuai dengan ajaran Islam.

Berdasarkan studi pendahulu penulis melihat gejala-gejala yang terjadi di SMA Negeri 2 Kelayang, seperti: (1) Guru kurang membiasakan siswa untuk mengucapkan salam ketika bertemu guru dan siswa yang lain; (2) Kurangnya kesopanan siswa ketika bertegur sapa dengan guru; (3) Kurangnya bimbingan dalam melaksanakana ibadah; dan (4) Siswa banyak bertutur kata kurang sopan dan mengucapkn kata-kata kotor.

Dari uraian di atas, penulis terdorong untuk melakukan penelitian dengan judul: "Upaya Guru Pendidikan Agama Islam dalam Pembentukan Kepribadian Islam Siswa di SMA N 2 Kelayang Kabupaten Indragiri Hulu".

Untuk mengarahkan masalah agar tidak menyimpang dari pembahasan, maka penulis membatasi penelitian ini hanya pada masalah: Upaya Guru Pendidikan Agama Islam dalam Pembentukan Kepribadian Islam Siswa di SMA N 2 Kelayang Kabupaten Indragiri Hulu. Dalam penelitian ini 
dikemukakan rumusan masalah sebagai berikut: "Apa saja upaya guru pendidikan agama Islam dalam pembentukan kepribadian Islam siswa di SMA N 2 Kelayang Kabupaten Indragiri Hulu?" Penelitian ini mempunyai tujuan untuk mengetahui upaya guru pendidikan agama Islam dalam pembentukan kepribadian Islam siswa di SMA N 2 Kelayang Kabupaten Indragiri Hulu .

\section{KONSEP TEORI}

\section{Hakikat Upaya Guru PAI}

Upaya adalah usaha, ikhtiar untuk mencapai suatu maksud, memecahkan persoalan, mencari jalan keluar (Depertemen Pendidikan Nasional, 2008:1534). Upaya adalah usaha mendidik dan mengembangkan citacita belajar (Dimyati dan Mudjiono, 2013:107).

Guru adalah satu komponen pendidikan yang memiliki peran dan fungsi yang amat strategis. Karena demikian pentingnya, hingga diantara pakar pendidikan ada yang berpendapat: "andaikata tidak ada kurikulum secara tertulis, tidak ada ruang kelas dan prasarana belajar mengajar lainnya, namun ada guru, maka pendidikan masih dapat berjalan (Abuddin Nata, 2012:343).

Guru adalah pekerja profesional yang secara khusus disiapkan untuk mendidik anak-anak yang telah diamanatkan orang tua untuk dapat mendidik anaknya disekolah. Guru atau pendidik sebagai orang tua kedua dan sekaligus penanggung jawab pendidikan anak didiknya setelah kedua orang tua didalam keluarganya memiliki tanggung jawab pendidikan yang baik kepada peserta didiknya. Guru merupakan penanggung jawab utama pendidikan anak melalui proses pendidikan formal anak yang berlangsung disekolah karna tanggung jawab merupakan konsekuensi logis dari sebuah amanat yang dipikulkan diatas pundak para guru (Novan Ardy Wiyani, 2012:97).

Sebagai pendidik profesional, guru bukan saja dituntut melaksanakan tugasnya secara profesional, tetapi juga harus memiliki pengetahuan dan kemampuan profesional. Guru harus dapat menempatkan diri dan menciptakan suasana yang kondusif, karena fungsi guru disekolah sebagai orang tua kedua yang bertanggung jawab atas pertumbuhan dan perkembangan jiwa anak (Sobry Sutikno, 2013:41-42).

Upaya guru pendidikan agama Islam adalah usaha sadar dan terencana dalam menyiapkan peserta didik untuk mengenal, memiliki, menghayati, hingga mengimani, bertaqwa dan berakhlak mulia dalam mengamalkan ajaran agama islam dari sumber utamanya kitab suci Al-Qur'an dan AlHadist. Melalui kegiatan bimbingan, pengajaran, latihan serta penggunaan pengalaman, disertai dengan tuntunan untuk menghormati penganut agama lain dan kerukunan antar umat beragama dalam masyarakat hingga terwujud kesatuan dan persatuan bangsa (Nurparidah dalam Abdul Mujib, 2015:10-11)

\section{Hakikat Kepribadian Islam}

Kepribadian berasal dari kata persona yang berarti topeng, yakni alat untuk menyembunyikan identitas diri. Kepribadian adalah organisani (susunan) dinamis dari sistem psikofisik dalam diri individu yang menentukan penyesuaiannya yang unik terhadap lingkungan (Djaali, 2006:2).

Kepribadian adalah totalitas karakteristik seseorang, sifat khas seseorang yang menyebabkan seseorang mempunyai sifat yang berbeda dari orang lain. Ada beberapa 
istilah yang sering digunakan dalam membahas kepribadian, yaitu konstitusi, tempramen, watak (Salmaini Yeli, 2012:76).

Ditinjau dari sudut historis etimologis istilah personality berasal dari bahasa latin persona yang berarti mengeluarkan suara. Sedangkan menurut istilah kepribadian adalah suatu organisasi yang dinamis dari sistem psikofisik individu yang memberikan corak yang khas dalam caranya menyesuaikan diri dengan lingkungannya (Baharuddin,2007:206210).

Defenisi yang umum dipergunakan tentang kepribadian: "personality is the dinamic organization within the individual of those psychophysical system that determine his unique adjustments to his environment" kepribadian adalah organisasi dinamis dalam diri individu sebagai sistem psikofisik, yang menentukan caranya yang khas (unik) dalam menyesuaikan diri dengan lingkungannya (Rif"at Syauqi Nawawi, 2010:15-16).

Kepribadian dalam Islam dikenal dengan istilah as-syakhsyiyah alislamiyyah yaitu serangkaian prilaku normatif manusia, baik sebagai makhluk individu maupun makhluk sosial, yang normanya diturunkan dari ajaran Islam, yang bersumber dari AlQur'an dan Al-Sunnah (Abdul Mujib, 2005:14). Menurut ajaran Islam manusia digambarkan memiliki dua unsur, yaitu unsur pisik, dan unsur non fisik (Salmaini Yeli,2012:86). Allah SWT berfirman:

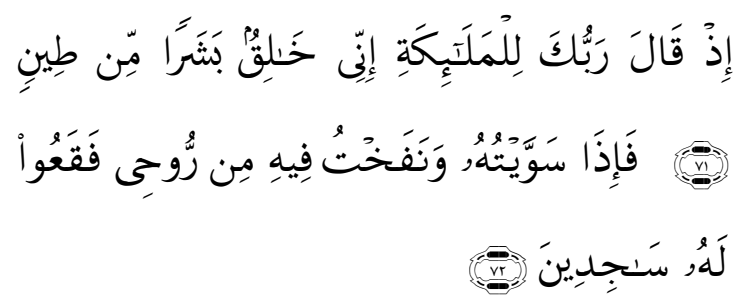

Artinya: "(Ingatlah) ketika tuhanmu berfirman kepada malaikat: "sesungguhnya aku akan menciptakan manusia dari tanah. Maka apabila telah ku sempurnakan kejadiannya dan ku tiupkan kepadanya roh (ciptaan) ku; maka hendaklah kamu tersungkur dengan bersujud kepadanya" (QS. Shaad, 38: 71-72).

Dalam Islam kepribadian merupakan salah satu faktor yang sangat penting, bahkan tujuan pendidikan Islam tertuju pada pembentukan kepribadian yang dimaksud. Tujuan pendidikan Islam adalah terwujudnya kepribadian seseorang yang membuatnya menjadi 'insan kamil' dengan pola taqwa (Salmaini Yeli, 2012:86).

\section{Bentuk-Bentuk Kepribadian dalam Islam}

Bentuk-bentuk kepribadian dalam Islam dibagi menjadi tiga bagian, yaitu kepribadian ammarah, lawwamah dan muthmainnah (Abdul Mujib, 2005:175). Kepribadian ammarah adalah kepribadian yang cendrung melakukan perbuatan-perbuatan rendah sesuai dengan naluri primitifnya, sehingga ia merupakan tempat dan sumber kejelekan dan perbuatan tercela. Ia mengikuti tabiat jasad dan mengejar pada prinsip-prinsip kenikmatan syahwati. Kepribadian lawwamah adalah kepribadian yang mencela perbuatan buruknya setelah memperoleh cahaya kalbu. Ia bangkit untuk memperbaiki kebimbangannya dan kadang-kadang tumbuh perbuatan yang buruk yang disebabkan oleh watak gelapnya, tetapi kemudian ia diingatkan oleh nur Ilahi, sehingga ia bertaubat dan memohon ampunan. 
Kepribadian muthma'innah adalah kepribadian yang tenang setelah diberi kesempurnaan nur kalbu, sehingga dapat meninggalkan sifat-sifat tercela dan tumbuh sifat-sifat yang baik. kepribadian ini selalu berorientasi kekomponen kalbu untuk mendapatkan kesucian dan menghilangkan segala kotoran (Abdul Mujib, 2005: 176-177).

Kepribadian mutma'innah terbagi tiga kategori sebagai berikut: (1) Kepribadian mukmin. Mukmin berarti orang yang beriman. Kata iman berarti percaya. Secara etimologi, iman berarti pembenaran (tashdiq). Orang yang beriman adalah orang benar dalam memegang dan melaksanakan amanat, sehingga hatinya merasa aman. Penghianatan terhadap amanat menjadikan kegelisahan, kecemasan dan ketakutan. Cabang-cabang iman diantaranya adalah mengucapkan kalimat thayyibah (mengucapkan syahadat), rasa malu, memberi makan orang yang membutuhkan, menebar salam kepada sesama muslim, memuliakan tamu, mencintai sesama muslim, mencintai rasul, tidak menyakiti fisik dan psikis yang lain, meramaikan masjid, baik budi pekerti, memenuhi janji, membantu dan meringankan beban orang miskin, menjawab do'a orang yang bersin, menghindari makanan atau minuman haram, tidak hasud, tidak berbicara dusta, tidak khianat terhadap kepercayaan orang lain, tidak mencuri milik orang lain, tidak melakukan zina dan sebagainya. Kepribadian mukmin terbagi menjadi enam bentuk kepribadian yaitu: (a) Kepribadian Rabbani. Istilah rabbani berasal dari kata $r a b b$ yang dalam bahasa indonesia berarti tuhan, yaitu tuhan yang memiliki, memperbaiki, mengatur, menambah, menunaikan, menumbuhkan, mengembangkan, memelihara, dan mematangkan sikap mental. Kepribadian rabbani adalah kepribadian individu yang didapat setelah menstranformasikan asma' (nama-nama) dan sifat-sifat tuhan kedalam dirinya dan kemudian diinternalisasikan dalam kehidupan nyata. Atau dalam bahasa yang sederhana kepribadian rabbani adalah kepribadian individu yang mencerminkan sifat-sifat ketuhanan (rabbaniyah).

Unsur-unsur ketuhanan yang terdapat pada diri manusia bermula dari konsep ruh. Struktur kepribadian manusia tidak hanya tersusun dari unsur-unsur jasmani, tetapi juga unsurunsur ruahani. Ruh yang berada dalam diri manusia diciptakan dan diberikan secara langsung oleh Allah SWT, tanpa melalui proses graduasi seperti jasad.

Terdapat dua pola untuk menuju pada kepribadian rabbani, pertama, pola yang merujuk pada asma' (namanama) atau sifat-sifat-Nya. Allah SWT memiliki 99 nama yang indah (al-asma al-husna), yang mana nama-nama itu merupakan sifat-sifat-Nya yang kamal (sempurna). Nama-nama itu diperkenalkan agar manusia mengetahui dan memahami nya. Kedua, pola yang merujuk pada implikasi psikologis setelah seseorang beriman kepada Allah SWT. pola ini diasumsikan dari pemikiran bahwa individu yang beriman kepadanya akan memiliki integrasi kepribadian lebih baik dari pada individu yang tidak beriman sama sekali; (b) Kepribadian Malaki. Istilah malaki berasal dari akar kata "malaka" yang berarti memiliki, mempunyai atau menguasai. Istilah malaki kemudian dinisbatkan dengan salah satu makhluk Allah yang disebut dengan malaikat. Kepribadian malaki adalah kepribadian individu yang didapat setelah menstransformasikan sifat-sifat malaikat kedalam dirinya untuk kemudian diinternalisasikan dalam kehidupan nyata. Atau dalam bahasa sederhana kepribadian malaki adalah 
kepribadian individu yang mencerminkan sifat-sifat kemalaikatan (malakiyyah).

Terdapat dua pola untuk menuju kepribadian malaki: pertama, pola yang merujuk pada tugas-tugas malaikat khusus. Kedua, pola yang merujuk pada sifat-sifat dan kegiatan-kegiatan (wadha'if) malaikat. Berdasarkan pola ini, bentuk umum kepribadian malaki adalah kepribadian nuri (bercahaya) sebab malaikat tercipta dari nur yang mampu menerangi kehidupan yang lain, baik jiwa maupun raga; (c) Kepribadian Qurani. Kepribadian qurani adalah kepribadian individu yang didapat setelah menstransformasikan isi kandungan Alqur'an kedalam dirinya untuk kemudian diinternalisasikan dalam kehidupan nyata. Atau dalam bahasa yang sederhana, kepribadian qur'ani adalah kepribadian individu yang mencerminkan nilai-nilai Alqur'an (qur'aniyyah); (d) Kepribadian Rasuli. Istilah rasuli berasal dari akar kata "rasala" yang berarti mengirim dan mengutus. Istilah rasuli kemudian dinisbatkan dengan salah satu status makhluk Allah Swt. Yang disebut dengan rasul (utusan). Kepribadian rasuli adalah kepribadian individu yang didapat setelah menstransformasikan sifat-sifat dan kelebihan-kelebihan rasul kedalam dirinya untuk kemudian diinternalisasikan dalam kehidupan nyata.

Terdapat dua pola dalam menuju kepribadian rasuli. Pertama, pola yang merujuk pada sifat-sifat khas seorang rasul. Sebagai manusia pilihan, rasul memiliki beberapa sifat utama, yang mana sifat-sifat utama itu disederhanakan dalam empat bentuk, yaitu Shidiq, amanah, tabligh dan fathanah. Kedua, pola yang merujuk pada kelebihan-kelebihan atau mu'jizat para rasul; (e) Kepribadian Yawm Akhiri. Istilah yawm akhiri berasal dari kata "yawm" (hari) dan "akhir" (akhir) yang berarti hari penghabisan atau penghujung. Kepribadian yawm akhiri adalah kepribadian individu yang didapat setelah mengimani, memahami dan mempersiapkan diri untuk memasuki hari akhir dimana seluruh prilaku manusia dimintai pertanggung jawaban; (f) Kepribadian Taqdiri. stilah taqdiri berasal dari akar kata qadara yang berarti ketetapan, aturan, hukum, kepastian dan keharusan universal. Kepribadian taqdiri adalah kepribadian individu yang didapat setelah mengimani, memahami, mengaplikasikan ketentuan dan aturan Allah SWT .

Kepribadian taqdiri tidak berarti mengubah ketentuan atau aturan Tuhan, melainkan memahami bahwa seluruh alam ciptaannya, termasuk manusia tidak dapat terlepas dari aturan dan ketentuan nya, serta menempuh aturan itu sebagaimana mestinya (Abdul Mujib, 2005: 185241).

\section{Kepribadian Muslim}

Muslim berarti orang Islam. Orang yang berislam adalah orang menyerah, tunduk, patuh, dalam melakukan perilaku yang baik, agar hidupnya bersih lahir dan batin yang pada gilirannya akan mendapatkan keselamatan dan kedamaian hidup di dunia dan akhirat. Penyerahan diri sepenuh hati pada zat yang mutlak membawa kedamaian yang sejati, ibarat seorang pasien yang diliputi ketakutan dan kehampaan hidup, kemudian ia menyerahkan persoalan pada psikiater maka ia akan mendapatkan kedamaian dan keselamatan. Kepribadian muslim disini meliputi lima rukun Islam, terdiri dari: (a) Kepribadian Syahadatain. Syahadatain berasal dari kata syahida yang berarti bersaksi, menghadiri, 
melihat, mengetahui dan bersumpah. Istilah syahadatain kemudian dinisbatkan pada satu momen dimana individu mengucapkan dua kalimat أشهد أن لا اله الا : الله وأشهد ان مدمد رسدل الله yang artinya: "aku bersaksi tiada tuhan selain Allah, dan aku bersaksi bahwasanya muhammad adalah utusan Allah". Kepribadian syahadatain adalah kepribadian individu yang didapat setelah mengucapkan dua kalimat syahadat, memahami hakikat dan ucapannya serta menyadari akan segala konsekuensi persaksiannya tersebut; (b) Kepribadian Mushalli. Mushalli adalah orang yang shalat. Shalat secara etimologi berarti memohon (do'a) dengan baik, yaitu permohonan keselamatan, kesejahteraan dan kedamaian hidup didunia dan akhirat kepada Allah Swt. Menurut istilah shalat adalah satu perbuatan yang diawali dengan takbir dan diakhiri dengan salam beserta mengerjakan syarat-syarat dan rukun-rukunnya. Kepribadian mushalli adalah kepribadian individu yang didapat setelah melaksanakan salat dengan baik, konsisten, tertib dan khusyu', sehingga ia mendapatkan hikmah dari apa yang dikerjakan. Pola kepribadian mushalli dapat dilihat dari beberapa sudut pandang: pertama, berdasarkan isyarat dari ayat-ayat Al-Qur'an atau Hadis yang berkaitan dengan Shalat. Kedua, berdasarkan isyarat pada bagian-bagian sholat seperti pada syarat-syarat, rukun-rukun dan sunnah-sunnahnya, baik didalamnya maupun diluarnya; (c) Kepribadian shaim. Shaim adalah orang yang berpuasa. Puasa secara timologi berarti menahan (al-imsak) terhadap sesuatu, baik yang bersifat materi maupun nonmateri. Menurut istilah puasa adalah menahan diri diwaktu siang dari segala yang membatalkandengan niat mulai terbit fajar hingga sampai terbenamnya matahari. Kepribadian shaim adalah kepribadian individu yang didapat setelah melaksanakan puasa dengan penuh keimanan dan ketakwaan, sehingga ia dapat mengendalikan diri dengan baik; (d) Kepribadian Muzakki. Muzakki adalah orang yang telah membayar zakat. Zakat secara etimologi berarti berkembang dan bertambah, baik secara kuantitas maupun kualitas.menurut istilah, zakat adalah mengeluarkan sebagian harta kepada orang yang berhak menerimanya ketika telah mencapai batasnya. Kepribadian muzakki adalah kepribadian individu yang didapat setelah membayar zakat dengan penuh keiklasan, sehingga ia mendapatkan hikmah dari apa yang dilakukan. Berdasarkan jenis-jenis zakat, infak dan sedekah, pola kepribadian Muzakki dibedakan atas: (1) wajib, seperti zakat fitrah, zakat harta benda, zakat hasil peternakan, zakat hasil pertanian, zakat logam mulia, zakat perdagangan dan zakat profesi. (2) sunnah, seperti sedekah yang bukan kategori wajib; dan (e) Kepribadian Haji. Haji secara etimologi berarti menyengaja pada sesuatu yang diagugkan. Menurut istilah, haji adalah menyengaja pergi ke baitullah untuk melaksanakan syarat, rukun dan wajibnya pada bulan yang ditentukan. Kepribadian haji adalah kepribadian individu yang didapat setelah melaksanakan haji yang semata-mata dilakukan karena Allah Swt, sehingga ia mendapat hikmah dari apa yang dilakukan (Abdul Mujib, 2005: 249-295).

\section{Kepribadian Muhsin}

Muhsin berarti orang yang berbuat ihsan. Kata ihsan berasal dari hasuna yang berarti baik atau bagus. Seluruh perilaku yang mendatangkan manfaat dan menghindarkan kemudharatan merupakan perilaku 
yang ihsan. Hadis nabi saw menyebutkan bahwa ihsan bermuara pada peribadatan dan muwajahah, dimana ketika sang hamba mengabdikan diri pada-nya, seakanakan bertatap muka dan hidup bersama dengan-nya, sehingga seluruh prilakunya menjadi baik dan bagus. Yang dimaksud dengan kepribadian muhsin adalah kepribadian dapat memperbaiki dan mempercantik individu, baik berhubungan dengan diri sendiri, sesamanya, alam semesta dan kepada tuhan yang diniatkan hanya untuk mencari ridhanya.

Kepribadian muhsin dapat dibentuk dengan dua pola, yaitu: (a) Pola umum, yaitu segala perilaku baik, yang dapat mempercantik diri manusia yang objeknya tidak terbatas pada subjek tertentu. Pola umum ini antara perilaku syukur, sabar, tawakal, pemaaf, iffah, dan sebagainya; dan (b) Pola khusus, yaitu segala prilaku baik, yang dapat mempercantik diri manusia yang objeknya ditujukan pada subjek tertentu. Misalnya, prilaku baik khusus pada Allah SWT, perilaku hormat anak kepada orang tua, perilaku sayang orang tua kepada yang lebih muda, perilaku taat istri kepada suami dan sebaliknya, perilaku santun guru kepada muridnya, perlakuan baik majikan kepada pembantu, berbuat baik kepada tetangga, berbuat baik kepada sesama manusia, sesama agama, sesama hamba Allah, dan seterusnya.

Dalam pencapaian kepribadian muhsin ini, terdapat tiga pola yang dapat diterapkan, yaitu: Pertama, pola hierarki, yang mana masing-masing karakter memiliki tata urut dan tahapan. Artinya, masing-masing karakter memiliki tangga yang harus dilalui dari tahap pertama menuju tahap berikutnya. Kedua, pola proporsional, yang mana individu dapat memiliki bagian-bagian dari kepribadian muhsin menurut keadaan yang dialami, tidak menuntut adanya tata urut. Bagi individu yang memiliki sifat-sifat agresif dan pemarah maka sabar merupakan karakter yang harus ditanamkanpada diri. Bagi individu yang materialis maka qana'ah merupakan karakter yang paling cocok diterapkan. Dan ketiga, pola elektis, yaitu menggunakan semua bentukbentuk kepribadian muhsin secara campuran dan simultan, sebab masingmasing bentuk kepribadian muhsin merupakan satu kesatuan yang utuh (Abdul mujib, 2005: 305-308).

\section{Struktur Kepribadian Islam}

Struktur kepribadian yang dimaksudkan disini adalah aspek-aspek atau elemen-elemen yang terdapat pada diri manusia yang karenanya kepribadian terbentuk. Pemilihan aspek ini mengikuti pola yang dikemukakan oleh Khayr Al-Din AlZarkali. Menurut Al-Zarkali, bahwa studi tentang diri manusia dapat dilihat melalui tiga sudut, yaitu: Pertama, Struktur jisim (Aspek fisik). Jisim adalah aspek diri manusia yang terdiri atas struktur organisme fisik. Organisme fisik manusia lebih sempurna dibandingkan dengan organisme fisik makhluk-makhluk lain. Pada aspek ini, proses penciptaan manusia memiliki kesamaan dengan hewan ataupun tumbuhan, sebab semuanya termasuk dari alam fisikal. Setiap alam biotik-lahiriah memiliki unsur yang sama, yakni terbuat dari unsur tanah, api, udara dan air. Keempat unsur tersebut merupakan materi yang abiotik (tidak hidup). Ia akan hidup jika diberi energi kehidupan yang bersifat fisik, energi kehidupan ini lazim disebut dengan nyawa.

Kedua, struktur ruh (Aspek psikis). Ruh merupakan substansi psikologis manusia yang menjadi esensi 
keberadaannya, baik didunia maupun diakhirat. Ruh membutuhkan jasad untuk aktualisasi diri. Ruh yang menjadi pembeda antara eksistensi manusia dengan makhluk lain. Pemahaman hakikat ruh sangat misteri, Allah SWT berfirman:

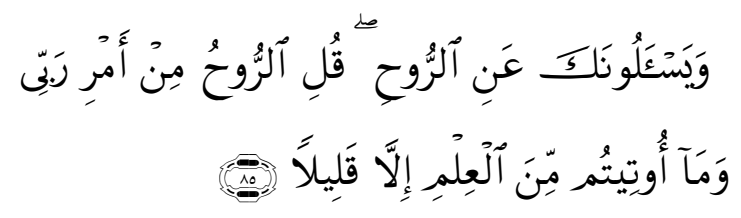

Artinya: "Dan mereka bertanya kepadamu tentang roh. Katakanlah: "Roh itu termasuk urusan Tuhan-ku, dan tidaklah kamu diberi pengetahuan melainkan sedikit". (QS. AlIsra', 17: 85).

Dari beberapa pengertian tenang ruh, dapat dipahami bahwa ruh itu memiliki tiga kemungkinan: pertama, ruh merupakan nyawa. Ia bukan jisim tetapi yang menghidupkan jisim. Ruh ini merupakan aksiden ('aradh), yaitu sesuatu yang baru dan singgah pada substansi jisim. Ia ada jika jisim ada dan menghilang apabila jasadnya rusak atau mati. Kedua, ruh sebagai substansi halus yang menyatu dengan badan manusia dialam khalq. Ruh ini terikat oleh hukum ruhani. Ruh inilah yang disebut dengan nafs. Ketiga, ruh sebagai substansi ruhani yang berasal dari alam amar (alam perintah) dan sedikitpun tidak terkait dengan alam khalq (alam penciptaan) yang terdiri dari unsurunsur jasmaniah.
Ketiga, struktur nafs (aspek psikofisik). Nafs memiliki arti psikofisik manusia, yang mana komponen jasad dan ruh telah bersinergi. Nafs memiliki natur gabungan antara natur jasad dan ruh. Apabila ia beriorientasi pada natur jasad maka tingkah lakunya menjadi buruk dan celaka, tetapi apabila mengacu pada natur ruh maka kehidupannya menjadi baik dan selamat.

Nafs adalah potensi psikofisik manusia yang secara inhern telah ada sejak jasad manusia siap menerimanya, yaitu usia empat bulan dalam kandungan. Nafs memiliki potensi gharizah. Gharizah berarti insting, naluri, tabiat, perangai, kejadian laten, ciptaan dan sifat bawaan.gharizah adalah potensi laten (terpendam) yang ada pada psikofisik manusia yang dibawanya sejak lahir dan yang akan menjadi pendorong serta penentu bagi tingkah laku manusia, baik berupa perbuatan, sikap, ucapan, dan sebagainya (Abdul Mujib, 2005:56-84).

Penelitian ini berkaitan dengan konsep upaya guru pendidikan agama islam dalam pembentukan kepribadian islam siswa di SMA Negeri 2 Kelayang, Indragiri Hulu.

Untuk mendapatkan data dilapangan guna dalam menjawab permasalahan-permasalahan tersebut, penulis perlu memberikan indikatorindikator upaya guru pendidikan agama Islam dalam pembentukan kepribadian Islam siswa dapat dikatakan baik apabila memenuhi dimensi-dimensi sebagai berikut:

Tabel 1:

\section{Dimensi dan Aspek Penelitian}

\begin{tabular}{|c|c|c|c|}
\hline No & Variabel & Dimensi & Aspek \\
\hline & $\begin{array}{l}\begin{array}{l}\text { Upaya guru PAI } \\
\text { dalam }\end{array} \\
\text { pembentukan }\end{array}$ & $\begin{array}{l}\text { Guru berupaya } \\
\text { membentuk siswa yang } \\
\text { memiliki kepribadian }\end{array}$ & $\begin{array}{l}\text { a. Guru mengupayakan kepribadian } \\
\text { rabbani pada diri siswa }\end{array}$ \\
\hline
\end{tabular}




\begin{tabular}{|c|c|c|c|c|}
\hline \multirow[t]{12}{*}{$\begin{array}{l}\text { kepribadian } \\
\text { islam siswa }\end{array}$} & \multirow{5}{*}{\multicolumn{2}{|c|}{ mukmin }} & b. & $\begin{array}{l}\text { Guru mengupayakan kepribadian } \\
\text { malaki pada diri siswa }\end{array}$ \\
\hline & & & c. & $\begin{array}{l}\text { Guru mengupayakan kepribadian } \\
\text { qurani pada diri siswa }\end{array}$ \\
\hline & & & $\mathrm{d}$. & $\begin{array}{l}\text { Guru mengupayakan kepribadian rasuli } \\
\text { pada diri siswa }\end{array}$ \\
\hline & & & e. & $\begin{array}{l}\text { Guru mengupayakan kepribadian yawm } \\
\text { akhiri pada diri siswa }\end{array}$ \\
\hline & & & f. & $\begin{array}{l}\text { Guru mengupayakan kepribadian } \\
\text { taqdiri pada diri siswa. }\end{array}$ \\
\hline & & \multirow{5}{*}{$\begin{array}{l}\text { Guru berupaya } \\
\text { membentuk siswa yang } \\
\text { memiliki kepribadian } \\
\text { muslim }\end{array}$} & a. & $\begin{array}{l}\text { Guru mengupayakan kepribadian } \\
\text { syahadatain pada diri siwa }\end{array}$ \\
\hline & & & b. & $\begin{array}{l}\text { Guru mengupayakan kepribadian } \\
\text { mushalli pada diri siswa }\end{array}$ \\
\hline & & & c. & $\begin{array}{l}\text { Guru mengupayakan kepribadian } \\
\text { sha'im pada diri siswa }\end{array}$ \\
\hline & & & d. & $\begin{array}{l}\text { Guru mengupayakan kepribadian } \\
\text { muzakki pada diri siswa }\end{array}$ \\
\hline & & & e. & $\begin{array}{l}\text { Guru mengupayakan kepribadian hajji } \\
\text { pada diri siswa. }\end{array}$ \\
\hline & & \multirow{2}{*}{$\begin{array}{l}\text { Guru berupaya } \\
\text { membentuk siswa yang } \\
\text { memiliki kepribadian } \\
\text { muhsin }\end{array}$} & a. & $\begin{array}{l}\text { Guru mengupayakan perilaku syukur, } \\
\text { sabar, tawakal dan pemaaf pada diri } \\
\text { siswa }\end{array}$ \\
\hline & & & b. & $\begin{array}{l}\text { Guru mengupayakan perilaku saling } \\
\text { menghormati, kasih sayang, sopan } \\
\text { santun pada diri siswa. }\end{array}$ \\
\hline
\end{tabular}

\section{METODE}

Penelitian ini merupakan penelitian studi kasus yaitu penelitian mengenai status subjek penelitian yang berkenaan dengan suatu fase spesifik atau khas dari keseluruhan personalitas. Tujuan penelitian ini adalah memberikan gambaran secara mendetail tentang latar belakang, sifat, serta karakter yang khas dari kasus, ataupun status dari individu, yang kemudian hasilnya dijadikan suatu hal yang bersifat umum (Misbahuddin, 2013:11).

Penelitian ini dilaksanakan dari bulan agustus sampai november 2016. Penelitian ini dilakukan di SMA Negeri 2 Kelayang kabupaten Indragiri Hulu.
Sebagai subjek dalam penelitian ini adalah guru PAI di SMA Negeri 2 Kelayang, Indragiri Hulu. Sedangkan yang menjadi objek dalam penelitian ini adalah upaya guru PAI dalam pembentukan kepribadian islam siswa di SMA Negeri 2 kelayang.

Populasi adalah obyek penelitian sebagai sasaran untuk mendapatkan dan mengumpulkan data (Joko Subagyo, 2006:23). Populasi dalam penelitian ini adalah guru PAI di SMA Negeri 2 Kelayang, Indragiri Hulu yang berjumlah 1 orang.

Pengumpulan data merupakan prosedur yang sistematik dengan memperhatikan penggarisan yang telah ditentukan. Hal ini dimaksudkan untuk menghindari data yang tidak terpakai 
karena jauhnya informasi yang diperoleh dengan keperluannya (Joko Subagyo, 2006:38). Adapun teknik pengumpulan data dalam penelitian ini sebagai berikut: (1) Wawancara. Wawancara adalah proses memperoleh keterangan untuk tujuan penelitian dengan cara tanya jawab sambil bertatap muka antara pewawancara dan informan atau orang yang diwawancarai (Burhan Bungin,2008: 111); dan (2) Dokumentasi. Dokumen merupakan catatan peristiwa yang sudah berlalu (Sugiyono, 2012:326). Dokumentasi biasanya dapat berupa data-data tertulis tentang profil sekolah, jumlah siswa, jumlah guru dan lain sebagainya.

Proses analisis merupakan usaha untuk menemukan jawaban atas pertanyaan perihal informasi, rumusanrumusan dan hal-hal yang kita peroleh didalam penelitian (Rizal Dairi, 2014:83).

Aktivitas dalam analisis data kualitatif dilakukan secara interaktif dan berlangsung secara terus menerus sampai tuntas, sehingga datanya sudah jenuh. Aktifitas dalam analisis data yaitu: (1) Reduksi Data (Data Reduction). Reduksi data merupakan proses berfikir sensitif yang memerlukan kecerdasan dan keluasan serta kedalaman wawasan yang tinggi. Dalam mereduksi data, setiap peneliti akan dipandu oleh tujuan yang akan dicapai. Tujuan utama dari penelitian kualitatif adalah pada temuan. Oleh karna itu, kalau peneliti dalam melakukan penelitian, menemukan segala sesuatu yang dipandang asing, tidak dikenal, belum memiliki pola, justru itulah yang harus dijadikan perhatian peneliti dalam melakukan reduksi data; (2) Penyajian Data (Data Display). Setelah data direduksi, maka langkah selanjutnya adalah mendisplaykan data. Dengan mendisplaykan data, maka akan memudahkan untuk memahami apa yang terjadi, merencanakan kerja selanjutnya berdasarkan apa yang telah difahami tersebut; dan (3) Conclusion Drawing/Verification. Langkah ketiga dalam analisis data kualitatif adalah penarikan kesimpulan dan verifikasi. Kesimpulan awal yang dikmukakan masih bersifat sementara, dan akan berubah bila tidak ditemukan buktibukti yang kuat yang mendukung pada tahap pengumpulan data berikutnya. Tetapi apabila kesimpulan yang dikemukakan pada tahap awal, didukung oleh bukti-bukti yang valid dan konsisten saat peneliti kembali kelapangan mengumpulkan data, maka kesimpulan yang dikemukakan merupakan kesimpulan yang kredibel (Sugiyono, 2012:336-343).

\section{HASIL}

\section{Gambaran Umum SMA Negeri 2 Kelayang}

SMA Negeri 2 Kelayang berdiri pada tahun 2000 yang awal nya diberi nama SMA 5 Koto Serumpun yang pada waktu itu menampung 5 Desa yaitu Desa Kota Medan, Tanah Datar, Titian Modang, Pulau Sengkilo dan Kuantan Tenang yang berinduk pada SMA Negeri 1 Peranap. Pada tahun 2001 didirikan bangunan baru oleh Pemerintahan Kabupaten Indragiri Hulu yang bakal cikal SMA Negeri 2 Kelayang dan pada tahun 2002 diganti SMA 5 Koto Serumpun menjadi SMA Negeri 2 Kelayang.

SMA Negeri 2 Kelayang terletak di Kabupaten Indragiri Hulu dengan batas-batas wilayah, sebagai berikut: (a) Sebelah Utara berbatasan dengan Kecamatan Sei Lala; (b) Sebelah Selatan berbatasan dengan Kecamatan Peranap; dan (c) Dan sebelah Timur berbatasan dengan Rakit Kulim. 
Luas SMA Negeri 2 Kelayang 9200 m. SMA Negeri 2 Kelayang memegang beberapa prinsip yang mendasar menurut peraturan Undang-Undang Nomor 20 Tahun 2003 tentang sistem pendidikan nasional yakni pendidikan diselenggarakan secara demokratis dan berkeadilan serta menjunjung tinggi hak asasi manusia, nilai keagamaan, nilai kultural, memberi keteladanan, membangun kemauan dan mengembangkan kreativitas peserta didik dalam proses pembelajaran. SMAN 2 Kelayang merupakan satuan dibidang pendidikan yang melaksanakan tugas dan fungsi sebagai sarana pendidik dan kependidikan.

Adapun visi SMA Negeri 2 Kelayang, yaitu: "Mewujudkan siswa/i yang beriman, berilmu, kreatif dan mandiri" dan misinya yaitu: Meningkatkan amal saleh; Menciptakan siswa berkepribadian beradap dan beradat; dan (3) Mengutamakan ilmu dan teknologi dalam kehidupan.

Sedangkan kurikulum yang digunakan oleh SMA Negeri 2 Kelayang pada saat ini adalah Kurikulum Tingkat Satuan Pendidikan (KTSP).

Adapun jumlah total siswa SMA Negeri 2 Kelayang pada saat ini yaitu 203 orang dengan jumlah siswa lakilaki sebanyak 99 orang dan siswa perempuan sebanyak 103 orang.

Upaya Guru Pendidikan Agama Islam dalam Pembentukan Kepribadian Islam Siswa di SMA Negeri 2 Kelayang Kabupaten Indragiri Hulu Sehubung dengan tujuan penulisan skripsi ini, yaitu untuk mengetahui Upaya Guru Pendidikan Agama Islam dalam Pembentukan Kepribadian Islam Siswa di SMA Negeri 2 Kelayang, maka penulis melakukan penelitian dengan teknik wawancara. Untuk memperoleh data yang diperlukan penulis melakukan wawancara dengan satu orang guru Pendidikan Agama Islam du SMA Negeri 2 Kelayang. Berikut hasil dari wawancara yang penulis lakukan dengan guru Pendidikan Agama Islam di SMA Negeri 2 Kelayang:

T : Apa saja upaya Ibu dalam membentuk kepribadian Rabbani pada diri siswa?

J: Sebenarnya kepribadian Rabbani merupakan salah satu bentuk kepribadian ideal dan semestinya telah dimiliki oleh seorang muslim. Jika kepribadian Rabbani dipahami sebagai kepribadian yang mencerminkan sifatsifat ketuhanan, maka setiap insan harus meneladani sifat-sifat yang dimiliki Allah. Kepribadian Rabbani dapat dibentuk dengan meneladani akhlak sang khaliq yang berupa Asmaul Husna. Mengajarkan kepada siswa untuk meneladani sifat-sifat Allah yang terkandung dalam Asmaul Husna misalnya, Allah memiliki nama ArRahman (yang maha pengasih) maka kita mengajarkan kepada siswa untuk menerapkan sifat tersebut dalam kehidupan sehari-hari contohnya mengasihi sesama teman dan lingkungan disekitar. Juga berupaya menjadikan siswa yang memiliki karakter mulia sebagaimana yang diperintahkan Allah SWT.

$\mathbf{T}$ :Apa saja upaya Ibu dalam membentuk kepribadian Malaki pada diri siswa?

J: Untuk membentuk siswa yang memiliki kepribadian Malaki atau malaikat, saya menjelaskan terlebih dahulu sifat-sifat malaikat serta hikmah beriman kepada malaikat. Saya mengajarkan kepada siswa untuk mencontoh sifat-sifat yang dimiliki oleh malaikat. Malaikat itu selalu taat dan patuh kepada perintah Allah SWT. Saya mengajarkan kepada siswa untuk selalu bersikap rendah hati dan tidak boleh sombong, mengajarkan kepada siswa 
untuk selalu tolong menolong apabila ada teman dalam kesusahan, selalu optimis serta semangat dalam belajar dan menggapai cita-cita, dan tidak boleh cepat putus asa dalam segala hal.

T :Apa saja upaya Ibu dalam membentuk kepribadian Qurani pada diri siswa?

J: Hal pertama yang dilakukan adalah memastikan bahwa siswa tersebut bisa membaca Al-Qur'an. Menerangkan kepada siswa Al-Qur'an adalah pedoman hidup dan petunjuk bagi umat manusia. Hal yang paling penting adalah menanamkan nilai-nilai Al-Qur'an pada diri siswa dan menjadikan siswa generasi Qurani yang mencintai Al-Qur'an. Seorang siswa diajarkan untuk selalu menghargai waktu karena Seorang yang menerapkan nilai al-Quran dalam kehidupannya, maka dia akan memanfaatkan tiap detik yang dikaruniakan Allah dengan hal-hal yang positif dan produktif, menghargai ilmu pengetahuan, memiliki budaya kerja keras karena Kerja keras adalah salah satu kunci sukses dalam menjalani hidup, pandai belajar dari sejarah, selalu konsisten dan istiqomah.

T : Apa saja upaya Ibu dalam membentuk kepribadian Rasuli pada diri siswa?

J: Dengan menanamkan sifat-sifat yang dimiliki rasul pada diri siswa, seperti sifat shidq (jujur), amanah (terpercaya), tabligh (menyampaikan) dan fatanah (cerdas). Serta menanamkan sifat-sifat terpuji lainnya misalnya sabar, adil, bijaksana, rendah hati dan suka menolong. Saya juga berupaya menanamkan aqidah yang kuat pada diri seorang siswa dan mengajarkan akhlakul karimah seperti yang dicontohkan oleh Rasulullah SAW, dengan demikian diharapkan siswa dapat terhindar dari perbuatan sesat dan merusak seperti; tawuran, mengkonsumsi narkoba, seks bebas, dan lain sebagainya.

T : Apa saja upaya Ibu dalam membentuk kepribadian Yawm Akhiri pada diri siswa?

J: Iman kepada hari akhir akan berdampak pada perilaku dalam keseharian. Sebagai seorang guru mempunyai tanggung jawab yang besar dalam mendidik siswanya. Hal ini juga akan dipertanggung jawabkan dihari akhir kelak. Saya mengajarkan perilaku yang mencerminkan iman kepada hari akhir terhadap siswa. Menerangkan kepada siswa bahwa kehidupan didunia hanya sementara, akan ada kehidupan yang kekal yaitu diakhirat. Menjelaskan kepada siswa untuk berhati-hati dalam melakukan segala perbuatan karena setiap perbuatan yang dilakukan akan dipertanggung jawabkan diakhirat kelak. Dan menanamkan kepada siswa perilaku selalu berusaha menjadi lebih baik, tidak silau dan terperdaya dengan kehidupan dunia, tidak memiliki rasa iri atas nikmat orang lain, rendah hati, selalu optimis dan lapang dada.

T : Apa saja upaya Ibu dalam membentuk kepribadian Taqdiri pada diri siswa?

J: Allah SWT menciptakan manusia dengan seluruh potensi manusiawinya. Sebagai seorang guru kita harus bisa menjelaskan kepada siswa bahwa kita hidup dimuka bumi ini sudah ditetapkan Allah dengan ketetapan dan takdirnya masingmasing. Sebagai hamba Allah kita hendaklah patuh terhadap takdir Allah tersebut. Sebagai guru juga harus mampu menjelaskan dan memberikan contoh ketetapan-ketetapan Allah kepada siswa, misalnya siswa harus memiliki jiwa yang optimis dalam belajar dan mencapai cita-cita, tidak sombong dan angkuh ketika mendapat kesuksesan, tidak pesimis, stres dan depresi ketika memperoleh kegagalan. Karena setiap yang kita lakukan telah 
ada ketetapan dari Allah SWT. Setiap manusia diciptakan oleh Allah dengan kelebihan dan kekurangannya masingmasing.

\section{T : Apa saja upaya Ibu dalam membentuk kepribadian Syahadatain pada diri siswa?}

J: Sebagai seorang muslim kita harus memiliki jiwa yang syahadat. Cinta dengan Allah Rasulnya. Sebagai guru saya harus mampu menanamkan karakter syahadatain pada diri siswa. Saya harus mampu menjelaskan kepada siswa hanya Allah SWT yang patut disembah dan dipatuhi, sebab dia merupakan zat segala-galanya. Hendaklah kita melaksanakan semua perintahnya dan menjauhi segala larangannya. Kita hendaknya juga selalu cinta dan mematuhi perintah rasul serta berusaha menauladani tingkah lakunya yang mulia.

T : Apa saja upaya Ibu dalam membentuk kepribadian Mushalli pada diri siswa?

J: Kepribadian Mushalli itu bagaimana caranya seseorang itu berkomunikasi secara baik dengan Allah dan sesama manusia. Berkomunikasi dengan Allah ditandai dengan takbir, sedangkan berkomunikasi dengan sesama manusia ditandai dengan salam. Saya mengajarkan kepada siswa cara berkomunikasi dengan Allah melalui takbir dalam Sholat, saya juga mengajarkan kepada siswa tata cara solat dan menyarankan kepada siswa agar melaksanakan Sholat lima waktu ataupun Sholat sunnah lainnya serta menjelaskan Sholat merupakan kewajiban yang tidak dapat dibatalkan oleh kepentingan sesaat. Komunikasi dengan sesama manusia pun akan bermutu tinggi apabila didahului dengan komunikasi Ilahi, sebab dengan begitu jiwa raganya akan bersih dan suci. Salam diakhir Sholat itu juga mencerminkan simbol tingkah laku yang nyata. Saya juga mengajarkan kepada siswa bahwa seseorang yang memiliki kepribadian Mushalli juga harus selalu bersih dan suci baik lahir maupun bathin. Kesucian lahir yang diwujudkan dalam wudhu dan kesucian batin dalam bentuk keiklasan dan kekhusukan.

\section{T : Apa saja upaya Ibu dalam} membentuk kepribadian Sha'im pada diri siswa?

J: Kepribadian Sha'im merupakan kepribadian orang yang berpuasa. Saya mengajarkan kepada siswa untuk melaksanakan puasa. Mengajarkan bagaimana tata cara puasa dan hal-hal lain yang berhubungan dengan puasa. Saya juga menjelaskan kepada siswa dengan berpuasa kita bisa ikut merasakan penderitaan yang orang lain rasakan, puasa juga mempunyai beberapa manfaat diantaranya melatih kesabaran dan membentuk kepribadian yang sehat. Serta mengajarkan kepada siswa selama melaksanakan puasa hendaklah melakukan perbuatan yang baik seperti bersedekah waktu berbuka dan sahur, Sholat malam dan tadarus Al-Qur'an.

T : Apa saja upaya Ibu dalam membentuk kepribadian Muzakki pada diri siswa?

J: Seorang siswa tentu belum mampu untuk mandiri, semua yang dilakukan masih bergantung dengan orang tua. Bagi seorang guru untuk menanamkan kepribadian Muzakki pada diri siswa bisa dilakukan dengan mengajarkan sikap rela berkorban. Bisa dimulai dari hal-hal kecil seperti bersedekah dan menolong yang membutuhkan.

T : Apa saja upaya Ibu dalam membentuk kepribadian Hajji pada diri siswa?

J: Siswa tentu belum mampu untuk melaksanakan Haji. Untuk menanamkan kepribadian Hajji pada diri siswa saya melakukan dengan 
mengajarkan kepada siswa tata cara berhaji. Saya harus mampu membentuk siswa yang memiliki kepribadian yang mengharamkan atau menahan diri terhadap perilaku yang dilarang, kepribadian yang selalu bekerja keras, kepribadian yang selalu melakukan halhal yang baik, kepribadian yang mandiri dan kepribadian yang pemaaf.

\section{T : Apa saja upaya Ibu dalam} membentuk perilaku syukur, sabar, tawakkal dan pemaaf pada diri siswa?

J: Sebagai seorang guru merupakan keharusan untuk menjadikan siswa yang memiliki perilaku syukur, sabar, tawakkal dan pemaaf. Saya mengajarka perilaku syukur, sabar, tawakkal dan pemaaf pada diri siswa melalui keseharian siswa tersebut disekolah. Misalnya melalui kegiatan belajar, siswa diajarkan untuk selalu bersyukur atas perolehan nilai jika belum memuaskan hendaklah belajar lebih giat lagi., tidak cepat bosan dan putus asa dalam mencapai cita-cita, rajin belajar serta menjadi pribadi yang pemaaf.

\section{T : Apa saja upaya Ibu dalam membentuk perilaku saling menghormati, kasih sayang dan sopan santun pada diri siswa?}

J: Untuk membentuk prilaku saling menghormati, kasih sayang dan sopan santun pada diri siswa bisa dilakukan dengan mengajarkan kepada siswa untuk bisa menghormati yang lebih tua misalnya dilingkungan sekolah siswa diajarkan bagaimana caranya menghormati guru, bagaimana bersikap sopan santun terhadap yang lebih tua, serta siswa juga diajarkan bagaimana cara menyayangi sesama teman dan lingkungan sekitar, tidak boleh ada permusuhan diantara sesama teman dan hendaklah menjaga lingkungan sekitar dengan tidak merusaknya. Dan saya menyarankan siswa untuk melaksanakannya dirumah dan lingkungan masyarakat sekitar.

\section{PEMBAHASAN}

Berdasarkan hasil wawancara yang telah diuraikan secara rinci terhadap data yang diperlukan, maka upaya guru dalam membentuk kepribadian Islam siswa di antaranya:

Pertama, Membentuk kepribadian Rabbani pada diri siswa, yaitu: (a) Meneladani Akhlak sang khaliq. Akhlak sang Khaliq berupa Asmaul Husna, Asmaul Husna bukan hanya untuk dihafal dan dilafal tetapi juga untuk diteladani agar disetiap langkah dan gerak kita Allah selalu bersama kita; dan (b) Mengajarkan kepada siswa untuk meneladani sifat-sifat Allah.Guru pendidikan agama Islam mengajarkan siswa untuk meneladani sifat-sifat yang dimiliki Allah seperti yang terkandung dalam Asmaul Husan misalnya Allah memiliki nama Ar-Rahman (yang maha pengasih) maka guru mengajarkan sifat tersebut pada diri siswa dan mengajarkan untuk menerapkannya dalam kehidupan sehari-hari.

Kedua, membentuk kepribadian Malaki pada diri siswa, yaitu: (a) Menjelaskan sifat-sifat malaikat dan hikmah beriman kepada malaikat. Seorang guru harus pandai dalam hal penyampaian materi terhadap siswanya, bagaimana agar materi yang disampaikan menarik bagi siswa. Guru pendidikan Agama Islam menjelaskan sifat-sifat dan hikamah beriman kepada malaikat serta menanamkan sifat-sifat yang dimiliki malaikat pada diri siswa; dan (b) Mencontoh sifat-sifat yang dimiliki malaikat. Guru pendidikan agama Islam mengajarkan kepada siswa untuk mencontoh sifat-sifat yang dimiliki malaikat, malaikat itu selalu patuh dan tunduk kepada Allah SWT sebagai manusia kita hendaknya juga patuh dan tunduk kepada Allah SWT 
dan selalu menanamkan sifat terpuji lainnya yang dimiliki malaikat.

Ketiga, membentuk kepribadian Qurani pada diri siswa, yaitu: (a) Memastikan siswa bisa membaca AlQur'an. Untuk mengetahui apakah setiap siswa memiliki kemampuan membaca Al-Qur'an, maka guru pendidikan agama Islam memberikan tes kepada setiap siswa untuk membaca Al-Qur'an, dan mengajarkan siswa yang belum terlalu lancar membaca Al-Qur'an; (b) Menerangkan kepada siswa Al-Qur'an adalah pedoman hidup dan petunjuk bagi umat manusia. Guru pendidikan agama Islam menerangkan kepada siswa bahwa AlQur'an adalah pedoman hidup dan petunjuk bagi umat manusia agar siswa senantiasa menggunakan akal pikirannya dalam melakukan segala hal dan menghindari hal-hal yang merusak; (c) Menanamkan nilai-nilai Al-qur'an pada diri siswa. Guru pendidikan agama Islam menanamkan nilai-nilai yang terkandung dalam Al-Qur'an agar siswa bisa memiliki kepribadian yang baik dan menjadi pribadi yang selamat dunia dan akhirat; dan (d) Menjadikan siswa generasi Qurani yang mencintai Al-Qur'an. Siswa yang memiliki kepribadian Qurani senantiasa melantunkan ayat-ayat Al-Qur'an dan memahami makna yang terkandung dalam Al-Qur'an. Serta senantiasa menanamkan nilai-nilai yang terkandung dalam Al-Qur'an dalam kehidupan sehari-hari.

Keempat, membentuk kepribadian Rasuli pada diri siswa, yaitu: (a) Menanamkan sifat-sifat yang dimiliki rasul pada diri siswa. Guru pendidikan agama Islam menanamkan sifat-sifat yang yang dimiliki rasul pada siswa agar siswa memiliki kepribadian yang baik dan mencerminkan sifat-sifat yang dimiliki rasul; (b) Menanamkan sifatsifat terpuji. Guru pendidikan agama Islam menanamkan sifat-sifat terpuji pada siswa agar siswa menjadi pribadi yang baik dan bisa menjadi contoh yang baik untuk yang lainnya; (c) Menanamkan Akidah yang kuat pada diri siswa. Tujuan utama menanamkan Akidah pada diri siswa agar siswa bisa membedakan mana yang benar dan mana yang salah serta untuk menghindari pengaruh-pengaruh yang buruk dalam kehidupan; dan (d) Mengajarkan Akhlakul karimah. Akhlakul karimah sangat perlu untuk diajarkan kepada siswa, Akhlak tercipta dari kebiasaan-kebiasan yang sering dilakukan. Guru mengajarkan akhlak yang baik kepada siswa agar siswa bisa membiasakan dalam kehidupan seharihari.

Kelima, membentuk kepribadian Yawm Akhiri pada diri siswa, yaitu: (a) Menerangkan kepada siswa bahwa kehidupan dunia hanya sementara, akan ada kehidupan yang kekal yaitu akhirat; (b) Guru pendidikan agama Islam menerangkan kepada siswa bahwa kehidupan yang sebenarnya adalah diakhirat kelak, yaitu tempat dimana kita mempertanggung jawabkan semua perbuatan yang pernah kita lakukan; (c) Menjelaskan kepada siswa untuk berhati-hati dalam segala perbuatan. Guru pendidikan agama Islam menjelaskan kepada siswa hendaklah memperbanyak melaksanakan ibadah dan amal saleh karena semua perbuatan yang dilakukan akan mendapat pertanggung jawabannya diakhirat kelak; dan (d) Menanamkan kepada siswa perilaku selalu berusaha menjadi lebih baik. Guru pendidikan agama Islam menanamkan perilaku yang baik terhadap siswa, dan guru pendidikan agama Islam juga menganjurkan kepada siswa untuk selalu memperbanyak amal-amalan yang baik agar kehidupan diridhai Allah SWT.

Keenam, membentuk kepribadian Taqdiri pada diri siswa, yaitu: (a) 
Menjelaskan kepada siswa kita hidup dimuka bumi ini sudah ditetapkan Allah. Guru pendidikan Agama Islam berupaya menjelaskan kepada siswa hidup dimuka bumi sudah ditetapkan Allah dengan ketetapan dan takdirnya masing-masing. Sebagai hamba Allah kita hendaknya patuh terhadap takdir Allah tersebut; dan (b) Menjelaskan dan memberi contoh ketetapan Allah kepada siswa. Guru pendidikan agama Islam memberikan contoh ketetapan Allah kepada siswa, misalnya siswa diharuskan memiliki jiwa yang optimis dan diharapkan siswa dapat menerapkannya dalam lingkungan seharai-hari.

Ketujuh, membentuk kepribadian Syahadatain pada diri siswa, yaitu: (a) Menanamkan karakter Syahadatain pada diri siswa. Guru pendidikan agama Islam menjadikan siswa memiliki karakter yang bertauhid yang mengakui akan ke-Esaan Allah dan meyakini nabi Muhammad adalah Rasul yang terakhir; dan (b) Menjelaskan kepada siswa hanya Allah yang patut disembah dan dipatuhi. Guru pendidikan agama Islam menjelaskan kepada siswa Allah merupakan zat segala-galanya, tempat meminta dan memohon pertolongan. Hendaklah kita melaksanakan semua perintahnya dan menjauhi semua larangannya.

\section{Kedelapan,}

membentuk kepribadian Mushalli pada diri siswa, yaitu: (a) Mengajarkan kepada siswa cara berkomunikasi dengan Allah melalui takbir dalam Sholat. Guru pendidikan Agama Islam mengajarkan kepada siswa untuk melaksanakan solat dengan baik agar komunikasi yang dilakukan manusia dengan Allah melalui Sholat dapat terlaksana dengan baik; (b) Menjelaskan tata cara Sholat kepada siswa. Guru pendidikan agama Islam menjelaskan tata cara Sholat kepada siswa agar siswa dapat memahami apa saja yang menjadi rukun, sunnah, yang membatalkan Sholat serta dapat melaksanakan Sholat dengan baik; dan (c) Menyarankan kepada siswa untuk melaksanakan Sholat. Guru pendidikan agama Islam menyarankan kepada siswa untuk melaksanakan Sholat karena dengan Sholat jiwa menjadi tentram dan damai serta kita bisa lebih dekat dengan Allah, serta Sholat merupakan kewajiban yang tidak dapat dibatalkan oleh kepentingan sesaat.

Kesembilan, membentuk kepribadian Sha'im pada diri siswa, yaitu: (a) Mengajarkan kepada siswa untuk melaksanakan puasa. Guru pendidikan agama Islam mengajarkan pelaksanaan puasa kepada siswa, dan menjelaskan kepada siswa bahwa dengan melaksanakan puasa kita bisa merasakan penderitaan orang lain dan kita juga bisa merasakan kebaikankebaikan yang kita peroleh selama melaksanakan puasa; dam

Mengajarkan kepada siswa selama melaksanakan puasa hendaklah melakukan perbuatan yang baik. Guru pendidikan agama Islam mengajarkan kepada siswa untuk melakukan kebaikan selama melaksanakan puasa agar puasa yang dilakukan mendapat keberkahan dari Allah.

Kesepuluh, membentuk kepribadian Muzakki pada diri siswa, yaitu dengan Mengajarkan sikap rela berkorban kepada siswa. Guru pendidikan agama Islam mengajarkan sikap rela berkorban kepada siswa, bisa dimulai dari hal-hal kecil seperti bersedekah dan menolong yang membutuhkan. Agar kita bisa membantu dan meringankan beban orang-orang yang fakir.

Kesebelas,

membentuk kepribadian Hajji pada diri siswa, yaitu: (a) Mengajarkan kepada siswa tata cara berhaji. Guru pendidikan agama Islam mengajarkan tata cara berhaji kepada siswa agar siswa mengetahui tahapan- 
tahapan dalam pelaksanaan haji, hal ini diharapkan juga untuk memotivasi siswa agar lebih giat lagi dalam melaksanakan ibadah; dan (b) Membentuk siswa yang memiliki kepribadian yang mengharamkan atau menahan diri terhadap perilaku yang dilarang, membentuk siswa yamg memiliki kepribadian yang selalu bekerja keras, kepribadian yang selalu melakukan hal-hal yang baik, kepribadian yang mandiri dan kepribadian yang pemaaf

Keduabelas, membentuk perilaku Syukur, sabar, tawakkal dan pemaaf pada diri siswa, yaitu dengan mengajarkan perilaku syukur, sabar, tawakkal dan pemaaf pada siswa melalui keseharian siswa tersebut disekolah. Guru pendidikan agama Islam bisa mengajarka perilaku syukur, sabar, tawakkal dan pemaaf pada diri siswa melalui keseharian siswa tersebut disekolah. Misalnya melalui kegiatan belajar, siswa diajarkan untuk selalu bersyukur atas perolehan nilai jika belum memuaskan hendaklah belajar lebih giat lagi., tidak cepat bosan dan putus asa dalam mencapai cita-cita, rajin belajar serta menjadi pribadi yang pemaaf.

Ketigabelas, membentuk perilaku saling menghormati, kasih sayang dan sopan santun pada diri siswa yaitu dengan mengajarkan perilaku saling menghormati, kasih sayang dan sopan santun pada siswa. Guru pendidikan agama Islam mengajarkan kepada siswa untuk bisa menghormati yang lebih tua misalnya dilingkungan sekolah siswa diajarkan bagaimana caranya menghormati guru, bagaimana bersikap sopan santun terhadap yang lebih tua, serta siswa juga diajarkan bagaimana cara menyayangi sesama teman dan lingkungan sekitar, tidak boleh ada permusuhan diantara sesama teman dan hendaklah menjaga lingkungan sekitar dengan tidak merusaknya. Dan guru menyarankan siswa untuk melaksanakannya di rumah dan lingkungan masyarakat sekitar.

\section{SIMPULAN}

Berdasarkan hasil analisis data yang dilakukan dapat disimpulkan bahwa upaya guru Pendidikan Agama Islam dalam pembentukan kepribadian Islam siswa di SMA Negeri 2 Kelayang kabupaten Indragiri Hulu meliputi beberapa aspek diantaranya mengajarkan tentang kepribadian Rabbani, Malaki, Qurani, Rasuli, Yawm Akhiri, Taqdiri, Syahadatain, Mushalli, Sha'im, Muzakki, Hajji, perilaku syukur, sabar, tawakkal, pemaaf, saling menghormati, kasih sayang dan sopan santun. Guru Pendidikan Agama Islam mempunyai peranan yang penting dalam membentuk kepribadian Islam tersebut pada diri siswa, begitu juga dengan guru Pendidikan Agama Islam di SMA Negeri 2 Kelayang. Upaya yang dilakukan adalah dengan memberikan penjelasan kepada siswa mengenai maksud dari kepribadian mukmin, muslim dan muhsin, guru juga memberikan contoh dan menyuruh siswa untuk mengaplikasikannya dalam kehidupan sehari-hari baik dilingkungan sekolah maupun dilingkungan masyarakat, guru juga mengajarkan kepada siswa untuk meneladani sifat-sifat yang baik sesuai dengan penjelasan dari materi dari kepribadian mukmin, muslim dan muhsin serta menanamkannya dikehidupan sehari-hari.

\section{DAFTAR RUJUKAN}

Ahmadi, Abu \& Soleh, Munawar. 2005. Psikologi Perkembangan. Jakarta: Rineka Cipta.

Al-Qur'an dan terjemahan. 
Baharuddin. 2007. Psikologi Pendidikan. Jogjakarta: Ar-Ruzz Media.

Bungin, Burhan. 2008. Penelitian Kualitatif. Jakarta: Kencana.

Busyro, Ahmad. 2011. Model Pembentukan Kepribadian Islam Siswa Melalui Pembelajaran Agama Islam Di SMA Negeri 1 Parung. Skripsi. Jakarta: Program Studi Pendidikan Agama Islam Fakultas Ilmu Tarbiyah Dan Keguruan UIN Syarif Hidayatullah.

Dairi, Rizal. 2014. Metodologi Penelitian. Pekanbaru: UIR PRESS.

Depertemen Pendidikan Nasional. 2008. Kamus Besar Bahasa Indonesia. Jakarta: PT. Gramedia Pustaka Utama.

Dimyati \& Mudjiono. 2013. Belajar dan Pembelajaran. Jakarta: Rineka Cipta.

Djaali. 2006. Psikologi Pendidikan. Jakarta: PT Bumi Aksara.

Efrianti, Leni. 2014. Peranan Guru PAI dalam Membentuk Kepribadian Muslim pada Siswa SMK Negeri 1 Bandar Sei Kijang Kabupaten Pelalawan. Skripsi. Pekanbaru: Program Studi Pendidikan Agama Islam Fakultas Agama Islam Universitas Islam Riau.

Hasbullah. 1996. Dasar-Dasar Ilmu Pendidikan. Jakarta: PT Raja Grafindo Persada.

Jamal, Nur. 2015. Transformasi pendidikan pesantren dalam pembentukan kepribadian santri. Jurnal Psikologi. Vol. 8, nomor 2.

Misbahuddin \& Hasan, Iqbal. 2013. Analisis Data Penelitian dengan Statistik. Jakarta:Bumi Aksara.
Mujib, Abdul. 2005. Kepribadian dalam Psikologi Islam. Jakarta: PT Raja Grafindo Persada.

Nata, Abuddin. 2012. Kapita Selekta Pendidikan Islam. Jakarta: PT Raja Grafindo Persada.

Nawawi, Syauqi, Rif'at. 2010. Kepribadian Qur'ani. Jakarta: Amzah.

Nurparida. 2015. Upaya Guru Pendidikan Agama Islam Mengatasi Problema Belajar Mengajar di SMA Negeri 2 Tanah Putih Kabupaten Rokan Hilir. Skripsi. Pekanbaru: Program Studi Pendidikan Agama Islam Fakultas Agama Islam Universitas Islam Riau.

Subagyo, Joko. 2006. Metode Penelitian dalam Teori Praktek. Jakarta:Rineka Cipta.

Rahmayandi, Helly. 2013. Peran Guru Aqidah sebagai Model dan Teladan dalam Pembentukan Kepribadian Siswa kelas VIII SMP Muhammadiyah 3 Yogyakarta. Skripsi. Yogyakarta: Program Studi Pendidikan Agama Islam Fakultas Tarbiyah dan Keguruan Universitas Negeri Sunan Kalijaga.

Sugiyono. 2012. Metode Penelitian Kombinasi (mixed methids). Bandung: Alfabeta.

Sutikno, Sobry. 2013. Belajar dan Pembelajaran. Lombok: Holistica.

Wiyani, Ardi, Novan \& Barnawi. 2012. Ilmu Pendidikan Islam. Jogjakarta: Ar-ruzz Media.

Yeli, Salmaini. 2012. Psikologi Agama. Pekanbaru: Zanafa Publishing. 